\title{
PHYSICAL CHARACTERISTICS OF MICROWAVE ASSISTED MOULDED FOAM FROM CASSAVA STARCH-CORN HOMINY
}

\author{
Endang Warsiki ${ }^{*}$, Evi Savitri Iriani ${ }^{2}$, Randi Swandaru1 \\ 1Department of Agroindustrial Technology, Faculty of Agricultural Technology, \\ Bogor Agricultural University, Darmaga Campus PO Box 220, Bogor 16602 \\ ${ }^{2}$ Indonesian Center for Agricultural Post-harvest Research and Development \\ Jalan Tentara Pelajar No.12 Bogor \\ E-mail : warsiki@yahoo.com.au
}

\begin{abstract}
Biodegradable foam is a packaging material made from renewable resources which is very prospective to substitute synthetic polystyrene foam. Starch is now dominantly use as a promising material to produce this foam due to its superior characteristic and its availability. However, starch is preferable as food source thus it is important to looking for a material such as corn hominy to reduce its usage in biopolymer production. Corn hominy is a byproduct of corn milling which has high content of starch and fiber. Its high fiber content could improve the strength of the foam. This research is aimed to formulate the composition of corn hominy and cassava starch to produce good quality of biodegradable foam. Polyvinyl alcohol (PVOH) is added for further better physical properties. The physical analysis showed that the composition of cassava starch and corn hominy feed has affected physical properties of biodegradable foam. Increasing the content of starch resulted on increasing of foam expansion. In contrast, the more starch content in the foam, the more brittle the foam will be. The best composition was given by ratio of $80 \%$-wt cassava starch and $20 \%$-wt corn hominy. The adding of PVOH affected the physical properties of less hardness and less brittle of the foam.
\end{abstract}

Keywords: biodegradable foam, cassava starch, hominy feed, PVOH

\begin{abstract}
Abstrak
Busa biodegradable merupakan bahan pengemas yang terbuat dari bahan nabati, ditujukan untuk subtitusi polistirena busa sintetik. Bio-polimer ini umumnya terbuat dari pati singkong karena ketersediaannya yang melimpah dan keunggulan sifat-sifat busa pati yang dihasilkan. Bagaimanapun, singkong adalah bahan pangan, sehingga bahan lain seperti ampok jagung perlu diujicobakan untuk mengurangi penggunaan singkong pada produksi bio-polymer ini. Ampok merupakan hasil samping dari penggilingan biji jagung. Kandungan serat ampok sangat tinggi dan diyakini dapat memperbaiki sifat fisis mekanis busa seperti meningkatkan kekuatan tarik dan mengurangi kerapuhan busa. Penelitian ini bertujuan untuk memformulasi komposisi pati singkong dan ampok jagung untuk memproduksi busa biodegradable berkualitas baik. Polivinil alkohol (PVOH) ditambahkan untuk membantu memperbaiki karakter fisik busa. Hasil penelitian menunjukkan bahwa rasio pati dan ampok mempengaruhi sifat fisik mekanis busa. Peningkatan kandungan pati dalam busa akan meningkatkan sifat rapuh bahan. Komposisi terbaik dihasilkan dari busa berbahan $80 \%$-b pati dan $20 \%$-b ampok. Penambahan PVOH dapat memperbaiki sifat fisik busa dengan menurunkan kekerasan dan kerapuhan.
\end{abstract}

Kata kunci: busa biodegradable, pati singkong, ampok jagung, PVOH

*corresponding author 


\section{Introduction}

Polystyrene foam is a plastic producing from petroleum styrene monomer in which now days is known as styrofoam. The use of polystyrene foam for food and electronics packaging lately has become a trend due to various advantages offering from this material, i.e. light, easy to form, good in keeping heat, and low cost production. However, the usage of styrofoam brings negative impact to the environment due to its biodegradable difficulty. US Environmental Protection Agency (EPA) stated that polystyrene foam is the fifth most dangerous garbage in USA. Furthermore, interaction between polystyrene foam and food can risk to the health due to its toxicity and carcinogenicity. The foam might leave monomer styrene in large numbers and migrate from the packaging to the food packaged. The World Health Organization's International Agency for Research on Cancer has found that polystyrene exposure can cause hormonal interference that may cause thyroid malfunction, breast cancer or even prostate cancer.

Due to it is widely used and has big negative impact; a substitution material is really needed to replace synthetic polystyrene foam. Agricultural and forestry material can be a good alternative to solve this problem, and among them, starch has a good prospect to producing bio-styrofoam (Zhou et al., 2006; Shey et al., 2006; Shogren et al., 2002). Commercially, bio-polymer is produces from starch. Starchy material which potential to be developed as bio-foam in Indonesia are corn and cassava because the two materials are abundantly available in this country. National corn production in 2009 was 16.3 million tons per year (Hadi and Elly, 2009). In 2014, national corn production is predicted more than 31.3 million tons. Unfortunately, corn and cassava is food staple thus the using of these kinds of starch is better to be reduced by finding other non food material.

As long as the corn is milled in the factory, hominy feed will be produced as a by-product. This hominy so far still has a lot content of starch and fiber thus it can be used perfectly for foam producing. Its starch content will reduce the percentage of cassava starch in bio-foam formulation and the fiber content will improve the strength of the foam itself. Literature (Andersen and Hodson, 1998) showed that starch foam tends to be brittle and fragile with poor water resistance (Fang and Hanna, 2001). Some fiber such as aspen fiber (Lawton et al., 2004), cellulose fiber (Salgado et al., 2008), wax (Fang and Hanna, 2001) and rubber latex (Shey et al., 2006) were added into starch master batch to improve bio-foam properties. Most research used baking technique to produce a foam (Salgado et al., 2008; Kaisangsri et al., 2011, Shey et al., 2006; Shogren et al., 2002), others used microwave assisted moulding process (Zhongdong et al., , 2005; Zhou et al., 2007; Richel et al., 2011). In the first method, starch/water batters is baked, heated mould in closed chamber, thus the starch gelatinized and foamed in a shape of mould. The technology is somewhat limited by the slow processing and necessary to dry off the moisture in the batter. On the other hand, second method involves a moulded starch foams from extruded pellets (Zhou et al., 2006; 2007) by converting starch/water batters into pellets with extrusion process and foamed the pellets by microwave heating. The feedstock was easily fed into the mold and the processing time was only a few second. In this technique, pellet has low moisture content thus it will produce better foam that it is resulted from baking method. The microwaveable starch pellets are also compact for transportation and storage compare to baking starch foam, and further it can be easily expanded using microwave when it is needed.

In this research, an additive of polyvinyl alcohol (PVOH) is added into the formula of cassava starch and corn hominy to improve foam characteristics. Furthermore, it necessary to examine the effect of adding $\mathrm{PVOH}$ and different ratio of cassava starch and corn hominy in producing biodegradable foam by microwave assisted moulding. Generally, PVOH will improve the foam properties (Mali et al., 2010; Shogren et al., 2002). It is reported that baked foams made from potato amylopectin, $\mathrm{PVOH}$ and aspen fiber appeared to have adequate flexibility and water resistance to function as a plate hot sandwich containers (Shogren et al., 2002). Flexibility of cornstarch foam plates increased slightly by adding PVOH (Mali et al., 2010). Cinelli et al. (2006) found the addition of $\mathrm{PVOH}$ to potato starch batters containing corn fiber mitigated the reduction in tensile properties and showed improved water resistance. Thus this research is aimed to examine the effect of adding $\mathrm{PVOH}$ and 
different composition ratio between cassava starch and corn hominy to physical characteristic of biodegradable foam.

\section{Methodology}

The main material in this research was cassava starch which purchased from Bogor local market, West Java and corn hominy feed which gathered from corn flour milling in Kediri, East Java. Aquadest was used as a plasticizer while PVOH (AR grade 99.8\% purity) and NaCL (AR grade) were obtained from commercial chemicals shop PT Setia Guna, Bogor.

\subsection{Methodology}

There were two steps of researches i.e preliminary and main research. The preliminary was aimed to dry and mill of the starch until obtaining the suitable size mesh of flour. Then, the hominy feed powder was analyzed its moisture, ash, fat, fiber, protein, and carbohydrate content. Batter was prepared by dry mixed of starch, corn hominy and $\mathrm{NaCl}$ and then water and $\mathrm{PVOH}$ were poured into it carefully. There were three different amount of water i.e 25, 35 and $45 \%$-wt out of total weight starch/hominy and the best dough was determined to produce pellet. To make sure the percentage of water in the batter, water content of flour was take into account thus theoretically it was used to correct water amount added into batter.

The main research was done based on the best batter resulted from the preliminary research. In this stage, trial the foam formulas in different set ratio of cassava starch and hominy feed as shown in Table 1 were carried out. $\mathrm{NaCl}, \mathrm{PVOH}$ and water added in each formula was also amounted in this table.
Thermoplastic pellet of starch was produced from the best batter formula and it was mixed in rheocor mixer (rheomix) 3000 HAAKE at $65 \mathrm{rpm}$ for 5 minutes. The temperatures were set in three different barrels ie. $90{ }^{\circ} \mathrm{C}, 100{ }^{\circ} \mathrm{C}, 90{ }^{\circ} \mathrm{C}$ for 5 minutes. The foaming tests were carried out in a combined microwave oven (Sharp R-8720M, 1000W), which allowed a combination of convection hot air and microwave heating. The closed mould loaded with pellets was positioned at the center of the rotating dish in the microwave oven and heated by microwave at $100 \%$ power of $1 \mathrm{~kW}$. About 45 $\mathrm{s}$ was required to foam the pellets depending on their compositions. The foam produced and then measured for its properties include glass transition temperature (Tg) by differential scanning calorimeter (DSC) and foam morphology by scanning electron microscopy (SEM). These two properties were only measured for the best formula produced from the main research. Furthermore, all sample for all set formulas were determined the hardness, expansion ratio; bulk density (ASTM D1895-65, 2010) and compression index (ASTM D1621-73, 2010).

\section{Results and Discussion}

\subsection{Preliminary research}

The results of proximate analysis of corn hominy powder were shown in Table 2. Based on these results, the water was added in the solution for foam producing as much as 25,35 and $45 \%$-wt with the moisture contents of cassava starch of $11.82 \%$-wt and hominy feed of 8.20\%-wt. However, $35 \%$-wt of water was the best and gave good batter which was easy to be palletized using rheometer and foamed using microwave oven. It was also founded that $5 \mathrm{~min}$ of plasticized process was the optimum time.

Table 1. Foam Starch Formulas of Cassava : Corn Hominy

\begin{tabular}{ccccccc}
\hline $\begin{array}{c}\text { Code of } \\
\text { sample }\end{array}$ & $\begin{array}{c}\text { Cassava starch } \\
\text { :corn hominy } \\
\text { (\%-wt) }\end{array}$ & $\begin{array}{c}\text { Cassava } \\
\text { starch } \\
\text { (g) }\end{array}$ & $\begin{array}{c}\text { Corn } \\
\text { hominy } \\
\text { (g) }\end{array}$ & $\begin{array}{c}\text { NaCl } \\
\text { (g) }\end{array}$ & $\begin{array}{c}\text { PVOH } \\
\text { (g) }\end{array}$ & $\begin{array}{c}\text { Water } \\
\text { (mL) }\end{array}$ \\
\hline A1B1 & $60: 40$ & 120 & 80 & 21 & 10 & 76 \\
A2B1 & $70: 30$ & 140 & 60 & 21 & 10 & 75 \\
A3B1 & $80: 20$ & 160 & 40 & 21 & 10 & 74 \\
\hline A1B2 & $60: 40$ & 120 & 80 & 21 & - & 76 \\
A2B2 & $70: 30$ & 140 & 60 & 21 & - & 75 \\
A3B2 & $80: 20$ & 160 & 40 & 21 & - & 74 \\
\hline
\end{tabular}


Table 2. Proximate Analysis of Corn Hominy Feed Powder

\begin{tabular}{lc}
\hline Component & $\begin{array}{c}\text { Percentage } \\
\text { (\%-wt) }\end{array}$ \\
\hline Water & 8.20 \\
Ash & 2.96 \\
Fiber & 9.68 \\
Fat & 14.93 \\
Protein & 9.85 \\
Carbohydrate & 54.38 \\
(by difference) & \\
\hline
\end{tabular}

\subsection{Main research}

A thermoplastic is kind of plastic properties in which soft when it is heated and back to hard when it is colded (Corradini et al., 2007). Pellet thermoplastic of starch was produced by mixed the starch dough (cassava and hominy feed as well as additives) with rheometer. The best composition of trial was given by ratio of 80 $\%$-wt cassava starch and $20 \%$-wt corn hominy feed. This ratio has given the highest expansion ratio and water absorption index with acceptable strength of the foam. Figure 1 show the photograph of visual of the pellet and foam.

\subsubsection{Glass Transition Temperature ( $\mathrm{Tg}$ )}

Base on the best composition (cassava starch:corn hominy 80:20 \%-wt), the thermal properties of glass transition temperature of the pellet and foam was measured as displayed in Table 3. It was shown that the extrudes, either from plasticized and expansion process, have been reached their

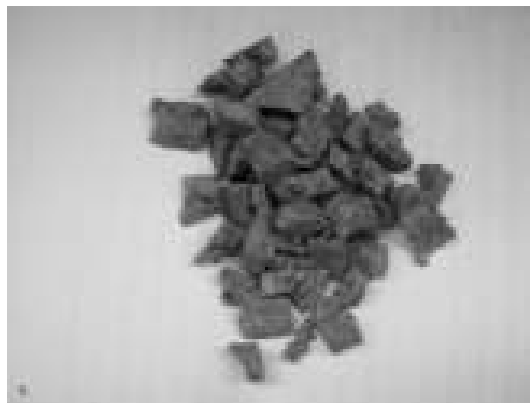

(a) glass transition temperatures. These glass transition data were important since it was a useful temperature ranges for practical applications especially while involving exposure foam to water as hot/cold water container. Bio-polymers foam with moderate glass transition temperatures tend to give more highly expanded and less friable starch foam. PVOH added in this sample has been affected on the increasing of the temperature of glass transition. Hydroxyl group of $\mathrm{PVOH}$ will improve the binding interaction between starch/hominy/water blend. Thus, it was believed that PVOH would improve the toughness of foam, reduce its brittleness and directly also improve its glass transition temperature. This finding was similar with other research (Mali et al., 2010) for foam made from starch and sugarcane bagasse fiber in which $\mathrm{PVOH}$ has improved of its expansion index and led to a significant reduction in water adsorption of starch foams, thus it generally improved foam properties.

\subsubsection{Scanning electron microscopy (SEM)}

SEM micrograph analysis along the surface of the foam with ratio of cassava and corn hominy 80:20 showed in Figure 2. It can be seen that formulas used in this research, both without and with $\mathrm{PVOH}$, has foamed perfectly indicating by none of starch granules remaining in the foam materials (Figure 2c and 2d). It did not also see many fibers that were extended out of the starch matrix. Pellet with PVOH content (Figure 2b)

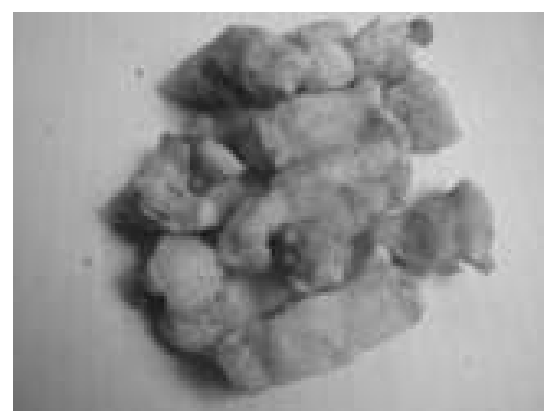

(b)

Figure 1. Cassava starch - corn hominy (a) pellet and (b) foam

Tabel 3. Glass Transition Temperature of Pellet and Foam

\begin{tabular}{lcc}
\hline \multirow{2}{*}{ Sample } & \multicolumn{2}{c}{ Glass Transition Temperature } \\
& $\left.{ }^{\circ} \mathbf{C}\right)$ & \\
\cline { 2 - 3 } & Pellet & Foam \\
\hline 80:20 without PVOH & 71.81 & 80.14 \\
80:20 with PVOH & 73.21 & 87.75 \\
\hline
\end{tabular}




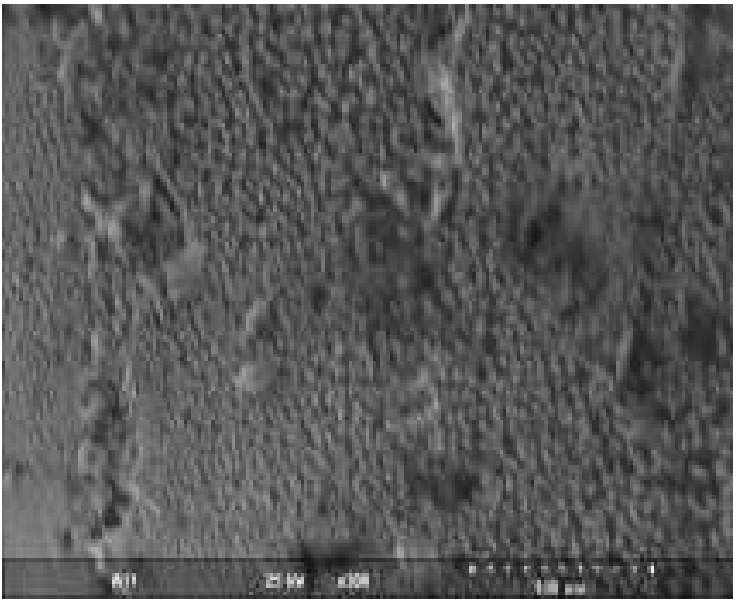

(a)

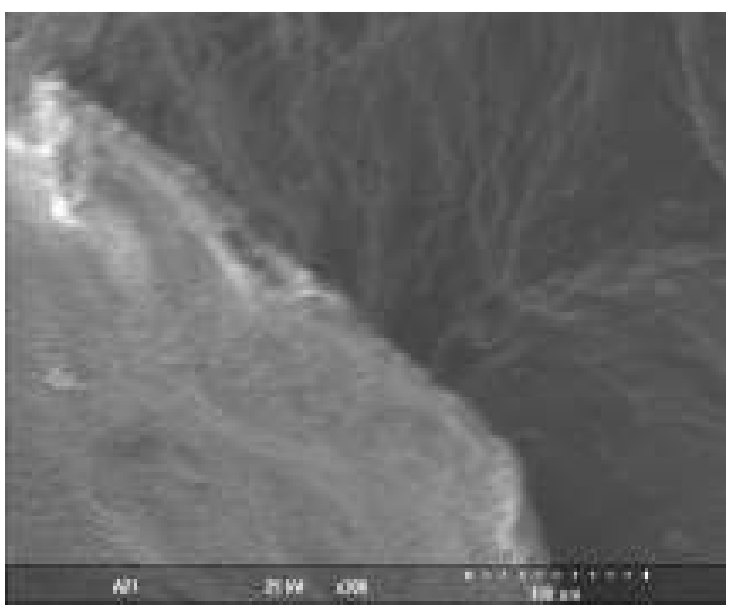

(c)

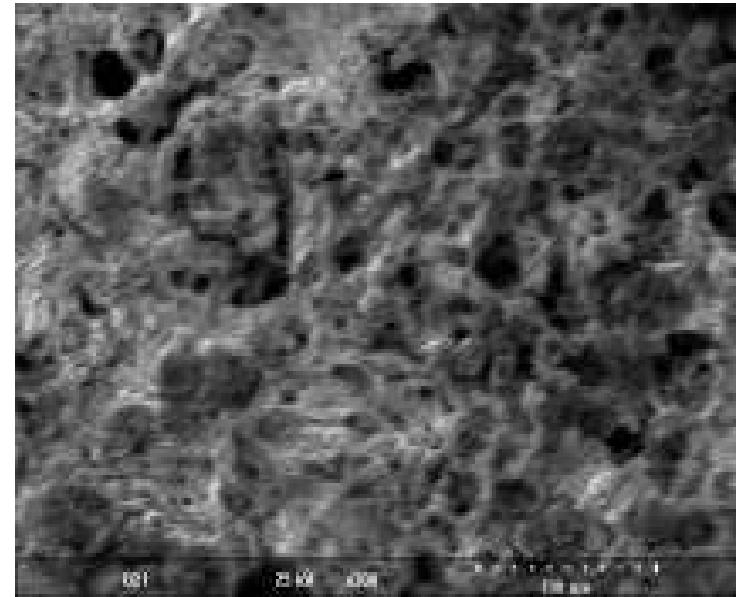

(b)

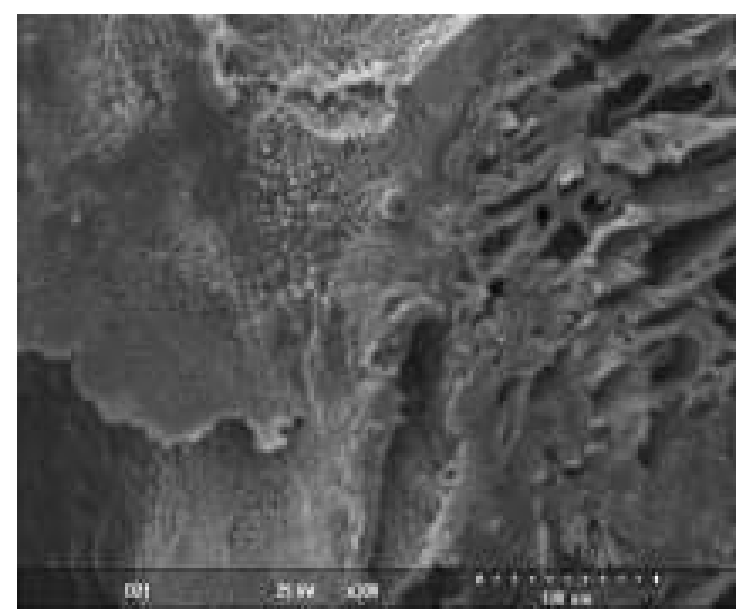

(d)

Figure 2. SEM at 300× magnification of pellet (a) without PVOH; (b) with PVOH and foam (c) without PVOH; (d) with PVOH

resulted in materials with good expansion compared to foams produced exclusively with starch only (Figure 2c). The effect of $\mathrm{PVOH}$ on homogeneity and expansion of pellet could be explained by the high compatibility between starch and $\mathrm{PVOH}$ as stated by Cinelli, et al., 2006, Although there may exist fusion lines between foamed pellets (Figure $2 \mathrm{c}$ and $2 \mathrm{~d}$ ) on the external surface of foamed blocks, most of pellets have been fully fused together in the interior of the blocks. Some interfaces between foamed pellets may be identifiable but it is difficult to identify any voids between pellets. No obvious difference in cell structure was observed when the expansion of pellets divers notably at the bottom and top of blocks (Figure 2c and 2d). A homogenous surface of starch and baggase fiber foam was also found by Mali et al. (2010).

\subsubsection{Hardness}

The hardness of the starch foam was shown in Figure 3. PVOH have been decreased the strength of the foam except in foam with ratio starch:hominy 70:40. Ratio of $80: 20$ had the highest value of $3.86 \mathrm{~mm} / 150$ $\mathrm{g} 5 \mathrm{~s}$, in meanwhile, the hardness of starch foam with PVOH was fluctuate. According to Cinelli et al. (2006), the addition of PVOH to starch foams leads to the formation of structures which are more resistant (less rigid) to compression, possibly due to the break of hydrogen bonds of starch and the PVOH content in the foam formulation. Starch can increase the hardness of foam thus consequently, foam will be brittle. In this case, starch acted as filler thus it made the foam hard. The harder of foam the more strength the foam will be. This phenomenon was in accordingly with Mali et al. (2010). 
However, PVOH improve foam properties by reducing the hardness and the brittleness.

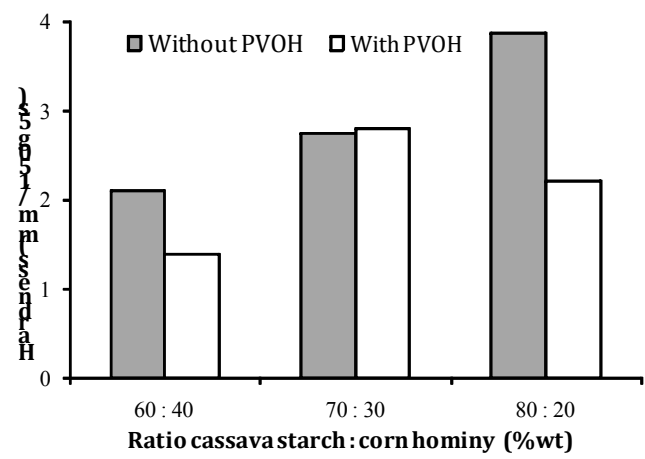

Figure 3. Hardness of cassava starch corn hominy foam

\subsubsection{Expansion ratio}

Expansion ratio is defined by ratio of volume between extrudate after expansion (foam) and extrudate before expansion (pellet). Like the density, this property is an important to define foam production cost. In general, extruded foams with lower densities have higher expansion index (Rhee et al., 1999; Xu and Hanna, 2005). Expansion ratio of samples with $\mathrm{PVOH}$ increased linearly to less cassava starch composition. The less content of the cassava starch, the higher the expansion ratio (Figure 4). Clearly, high starch content will increase density of pellets as well as their volume. Thus, with the same volume of expanding of foams, it will decrease the expansion ratio. It also can be seen from the figure that $\mathrm{PVOH}$ added in that formula has resulted on less expansion ratio. In can be understand that adding additive of PVOH will increase the mass of pellet and it will burden the pellet expanding to be foam.

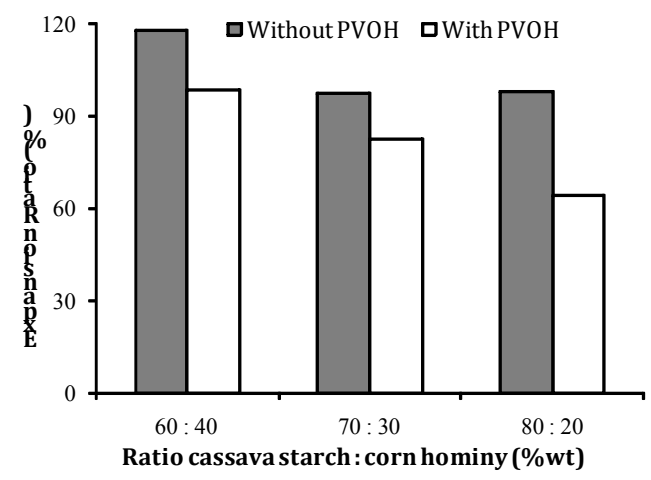

Figure 4. Expansion ratio of cassava starch - corn hominy foam

\subsubsection{Bulk density}

Bulk density is weight of foam (g) per unit volume $\left(\mathrm{mL}\right.$ or $\left.\mathrm{cm}^{3}\right)$. Small number of bulk density mean that the foam has a small weight, however the foam has placed in high volume. The bulk density of starch foam resulted in this research was figured in Figure 4. The higher cassava starch content in that foam, the less bulk density of foam. $\mathrm{PVOH}$ has also impacted this properties. PVOH-starch foam has higher bulk density than non PVOH-starch foam. That phenomenon was as same explanation as expansion ratio value. A research by Mali et al. (2010) has also found that foam density was positively influenced by linear effects of starch, fiber, and PVOH contents. Density is an important physical property of extruded foams. Low density was ideal for these products because it reduces production costs. Thus the foam with low density, as long as meet other properties requirement of foam such as hardness, strengness, expansion ratio and so on, was an ideal foam.

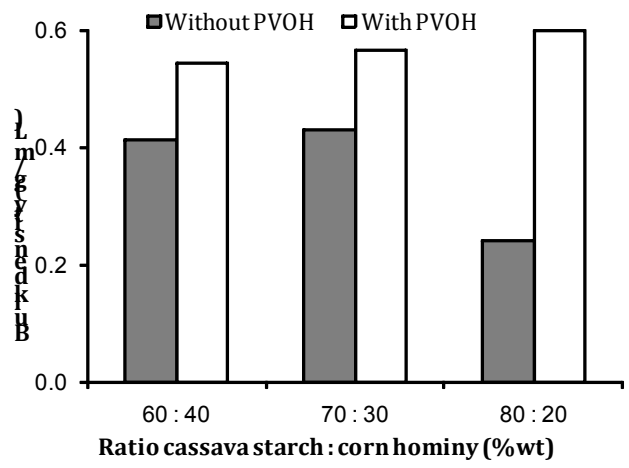

Figure 5. Bulk density of cassava starch corn hominy foam

\subsubsection{Compression}

Compression value is a result of the subjection of a material to compressive stress (in $\mathrm{kg}$ ), which results in reduction of volume. Compression is physical properties and it is important if the foam is purposed as packaging material because in somehow, package product will stacked in the warehouse. The high compression value of the foam the more load could be detained. Figure 5 showed the compression value of this foam in different composition of cassava starch and corn hominy. Statistically, there was no significantly different in the compression value due to the different of 
starch composition, either for PVOH starch foam and non PVOH starch foam. However, in the same composition of starch, PVOH foam generally has good compressibility compare to non PVOH foam, excepted for composition of $80 \%$-wt cassava starch and $20 \%$-wt hominy feed. The highest compressibility was about $25.985 \mathrm{kgf}$. This value was still low to meet the standard as about $99.046 \mathrm{kgf}$ of SNI 01-4853-2006 (2006). Further advances experiment in the incorporation of other fibers or fillers may help to improved mechanical properties, for tougher and greater compressive strength of the starch foam.

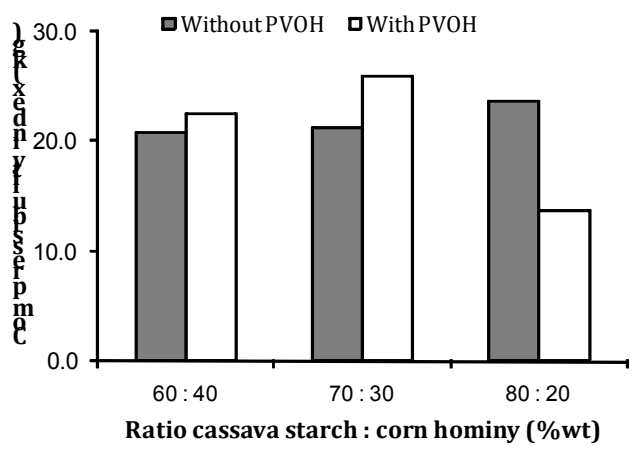

Figure 6. Compressibility index of cassava starch - corn hominy foam

\section{Conclusion}

It was concluded the best ratio for biodegradable foam producing was $80 \%$-wt of cassava starch and $20 \%$-wt of corn hominy flour. Furthermore, the physical properties of foam resulted in this research was affected by composition of cassava starch and the adding of PVOH. It was looked that increasing cassava starch containing in that foam has improve its hardness and expansion ratio. Contrary, high starch content has decreased the bulk density and compressibility of the foam. The properties of the foams depend largely on the starch moisture content and extrusion conditions. $\mathrm{PVOH}$ adding in the foam was good to improve the less hardness and high compressibility of the foam; however it revealed on less properties in the expansion ratio and bulk density. For commercial usage, the foam resulting from this research was still need improvement on water resistance by adding additives such as monostearyl citrate or coating it by wax or other water proof materials. As long as at room temperature usage with low humidity, this foam produced from this research was comparable to commercial application as polystyrene foam. Regarding to commercial use, another considerable effort must been made to improve the physical and mechanical properties of starch-based foams to meet with traditional plastic foams.

\section{References}

Andersen, P.; Hodson, S., Systems for moulding articles which include a hinged starch-bound cellular matrix, US Patent No. 5,705,203, 6 Jun 1998.

ASTM, Standard Test Methods for Apparent Density, Bulk Factor, and Pourability of Plastic Materials, D1895 - 96, 2010.

ASTM, Standard Test Method for Compressive Properties of Rigid Cellular Plastics, D162173, 2010.

Corradini, E.; Carvalho, A. J. F.; Curvelo, A. A. D.; Agnelli, J. A. M.; Mattoso, L. H. C., Preparation and characterization of thermoplastic starch/zein blends, Materials Research, 2007, 10(3), 236- 243.

Cinelli, P.; Chiellini, E.; Lawton, J. W.; Imam, S. H., Foamed articles based on potato starch, corn fibers and poly(vinyl alcohol), Polymer Degradation and Stability, 2006, 91(5), 1147-1155.

Fang, Q.; Hanna, M. A., Characteristics of biodegradable Mater-Bi ${ }^{\circledR}$-starch based foams as affected by ingredient formulations, Industrial Crops and Products, 2001, 13(3), 219-227.

Hadi, S.; Elly, S. R., Corn Production-Yearly Report, Department of Agriculture the Republic of Indonesia, Jakarta, 2009.

Kaisangsri, N.; Kerdchoechuen, $\quad$ 0; Laohakunjit, N., Biodegradable foam tray from cassava starch blended with natural fiber and chitosan, Industrial Crops and Products, 2011, 5(3), 127 - 134.

Lawton, J. W.; Shogren, R. L.; Tiefenbacher, K. F., Aspen fiber addition improves the mechanical properties of baked cornstarch foams, Industrial Crops and Products, 2004, 19(1), 41-48. 
Mali S.; Debiagi F.; Grossmann M. V. E.; Yamashita F., Starch, sugarcane bagasse fibre, and polyvinyl alcohol effects on extruded foam properties: A mixture design approach, Industrial Crops and Products, 2010, 32(3), 353-359.

National Standard Board, SNI 01-4853-2006 01-4853: Compressibility of Packaging, Department of Industry the Republic of Indonesia, Jakarta, 2006.

Rhee, K. S.; Cho, S. H.; Pradahn, A. M., Expanded extrudates from corn starch-lamb blends: process optimization using response surface methodology, Meat Science, 1999, 52(2), 127-134.

Salgado, P. R.; Schmidt, V. C.; Ortiz, S. E. M.; Mauri, A. N.; Laurindo, J. B., Biodegradable foams based on cassava starch, sunflower proteins and cellulose fibers obtained by a baking process, Journal of Food Engineering, 2008, 85(3), 435-443.

Shey, J.; Imam, S. H.; Glenn, G. M.; Orts, W. J., Properties of baked starch foam with natural rubber latex, Industrial Crops and Products, 2006, 24(1), 34-40.

Shogren, R. L.; Lawton, J. W.; Tiefenbacher, K. F.; Baked starch foams: starch modifications and additives improve process parameters, structure and properties, Industrial Crops and Products, 2002, 16(1), 69-79.

Richel, A.; Laurent, P.; Wathelet, B.; Wathelet, J.; Paquot, M., Microwave-assisted conversion of carbohydrates. State of the art and outlook, Comptes Rendus Chimie, 2011, 14(2-3), 224234.

Xu, Y.; Hanna, M. A., Preparation and properties of biodegradable foams from starch acetate and poly(tetramethylene adipate-co-terephthalate), Carbohydrate Polymer, 2005, 59(4), 521-529.

Zhongdong, L.; Peng, L.; Kennedy, J. F., The technology of molecular manipulation and modification assisted by microwaves as applied to starch granules, Carbohydrate Polymers, 2005, 61(3), 374-378.

Zhou, J.; Song, J.; Parker, R., Structure and properties of starch-based foams prepared by microwave heating from extruded pellets, Carbohydrate Polymers, 2006, 63(4), 466475.

Zhou, J.; Song, J.; Parker, R., Microwaveassisted moulding using expandable extruded pellets from wheat flours and starch, Carbohydrate Polymers, 2007, 69(3), 445-454. 